\title{
Pendekatan Kewarganegaraan Indonesia
}

\author{
Toba Sastrawan Manik*, Samsuri
}

Universitas Negeri Yogyakarta, Indonesia

\begin{abstract}
Abstrak-Dalam diskursus kontemporer, aliran pendekatan kewarganegaraan terdiri atas Liberal, Republikan, dan Komunitarian. Tujuan dari kajian ini ialah untuk mengkaji dan menjelaskan pendekatan kewarganegaraan yang digunakan di Indonesia. Metode penelitian yang digunakan adalah penelitian kualitatif menggunakan teknik pengumpulan data studi pustaka (library research). Sumber-sumber dalam penelitian ini ialah seperti buku, artikel hasil penelitian, dan dokumen-dokumen seperti UUD, Peraturan Pemerintah, dan Panduan-Panduan yang berkaitan dengan Pendidikan Pancasila dan Kewarganegaraan. Data diolah dan dianalisis secara indukatif. Hasil dari temuan

Kata kunci:

Aliran Kewarganegaraan

Pancasila

PPKn

\section{Histori:}

Dikirim: 10 Maret 2021

Direvisi: 15 Maret 2021

Diterima: 17 Maret 2021

Online: 18 Maret 2021 kajian ini ialah Pendekatan Kewarganegaraan Indonesia berbeda dengan pendekatan kewarganegaraan kontemporer. Pendekatan Kewarganegaraan Indonesia ialah pendekatan Pancasila yang merupakan sintesa dari ketiga aliran kontemporer. Ruang-ruang individu dan publik dilindungi dan dikembangkan oleh negara. Lebih dari itu, budaya masyarakat atau kearifan yang turut membentuk kehidupan masyarakat dilindungi dan dikembangkan \begin{tabular}{l} 
oleh negara sebagaimana termaktub dalam UUDNRI Tahun 1945. C2021 JCC. All rights reserved \\
\hline \hline cc (i) (-) A Author(s) agree that this article remains permanently open access under the terms of the Creative Commons
\end{tabular} Attribution-ShareAlike 4.0 International License
\end{abstract}

\section{Identitas Artikel:}

Manik, T. S., \& Samsuri, S. (2021). Pendekatan Kewarganegaraan Indonesia. Jurnal Citizenship Virtues, 1(1), 42-50.

\section{PENDAHULUAN}

Warga negara merupakan salah satu komponen penting dalam sebuah negara. Warga negara menjadi conditio sine qua non bukan karena formal eksistensial namun juga bersifat fungsional. Osler \& Starkey (2006: 15) menegaskan bahwa kewarganegaraan itu lebih dari status. Kewarganegaraan dalam konteks status semata mulai ditinggalkan dan dianggap terlalu sempit (Isin \& Turner, 2002).

Dalam kajian filsafat kewarganegaraan dikenal pendekatan kewarganegaraan liberal, kewarganegaran republikan, dan kewarganegaran multikulturalism. Ketiga kewarganegaraan tersebut memandang hubungan yang berbeda antara negara dan warga negaranya. Ketiga pendekatan tersebut juga digunakan oleh setiap negara sesuai dengan karakter negara masing-masing yang kemudian mempengaruhi bagaimana proses pembentukan (pendidikan kewarganegaraan) termasuk di dalamnya nilai-nilai yang diajarkan dan warga negara yang diharapkan. Metode penelitian yang digunakan adalah penelitian deskriptif kualitatif dengan metode

\footnotetext{
*Corresponding author

E-mail: tobasastrawanmanik@gmail.com
} 
penelitian studi dokumentasi. Pertanyaan-pertanyaan penelitian yang hendak didapatkan dalam penelitian ini ialah apa nilai-nilai filosofis kewarganegaraan yang diajarkan dalam pendidikan kewargaengaraan Indonesia? Apa pendekatan kewarganegaraan yang cenderung digunakan dalam sistem pendidikan Indonesia?

\section{Pendekatan Liberal}

Konsepsi kewarganegaraan Liberal berangkat dari penekanan individu. Individu mendapatkan posisi yang sangat sentral dan paling penting. Bahkan, pandangan liberal (Liberalism) bahwa individu merupakan bentuk seluruh agresi sosial termasuk negara (Schuck, 2002). Afirmasinya adalah agresi sosial termasuk negara membentuk konsepsi yang bersifat sentripugal di mana pusatnya adalah individu. Dalam pandangan ini semua pranata dan struktur sosial harus menjamin, melindungi, bahkan menguat individu tersebut. Sederhananya adalah individu merupakan yang paling utama (Faulks, 2002). Dalam bahasa Kivisto \& Faist (2007) Liberalisme adalah gagasan yang fokus pada masalah bagaimana memaksimalkan hak-hak individu. Dalam upaya memaksimalkan hak-hak individu tersebut, salah satu caranya ialah dengan meminimalisir peran dan keterlibatan negara.

Pandangan liberal merupakan kritik dan perlawan terhadap feodal yang diskriminatif dengan mendefinisikan politik dan peluang ekonomi individu oleh keanggotaan grup tertentu. Berdasarkan pengalaman tersebut, demokrasi liberal menekankan kesetaraan dan kemerdekaan warga negaranya sebagai komitmen dasarnya (Kymlicka, 1995). Hal ini kemudian menuntut pentingnya menghargai dan memandang setiap individu berbeda (Honohan, 2017). Tokoh yang cukup terkenal dengan gagasan Liberal adalah John Locke dan John Stuart Mill. Locke (dalam Tuckness, 1999; Gardner, 1993; Forde, 2009) memandang semua individu dianugerahi oleh Tuhan oleh akal atau yang disebutnya dengan Suara Tuhan (The Voice of God). Berkah ini yang kemudian menurut Locke (dalam Kivisto \& Faist, 2007) memungkinkan manusia untuk berpikir dan bertindak sesuai dengan hukum alam.

Mill (dalam Nain \& Yusoff, 2003) memiliki gagasan yang lebih maju dan sistematis tentang Liberalisme. Mill (dalam Schuck, 2002) bahkan lebih keras mengatakan bahwa kebebasan berpikir, beribadah, dan berekspresi yang bebas sebebasnya (tidak terhalang) merupakan jalan terbaik menuju kebenaran dan perbaikan kehidupan sosial. Sekalipun Mill mengakui kebebasan bertindak manusia harus lebih dibatasi dibandingkan kebebasan berpikirnya. Dalam hal ini Mill menganjurkan agar dibuat sebuah hukum yang menciptakan dan mempertahankan otonomi individu dan promosi diri dengan meminimalisir intervensi pemerintah.

Berdasarkan hal tersebut, menurut Mill relasi individu dan pemerintah bersifat bertentangan satu sama lain. Di mana individu menguat maka negara harus melemah. Hanya dalam kategori tertentu aksi negara menguatkan individu yakni saat penegakan hukum dan kepentingan publik (Schuck, 2002). Oleh karena itu, Menurut Vincent (2010) warga negara dalam liberalisme individual adalah warga negara yang "minimal" karena secara esensial dianggap sebagai cerminan dari konsepsi prosedural negara yang minim.

Keuntungan dari gagasan konsepsi liberal ialah khususnya bagi pendukungnya adalah gampang untuk diamati. Maksudnya adalah konsep individu yang digariskan mudah untuk diterapkan dan dirasakan oleh individu. Sebab yang menjadi tolok 
ukur adalah individu itu sendiri. Warga negara membentuk pendapat mereka sendiri, mengejar proyek mereka sendiri, dan bertransaksi bisnis sendiri yang tidak dijebak oleh negara agenda politik dan kekuatan paksaan, kecuali sejauh tindakan individu melibatkan kepentingan anggota masyarakat lainnya, telah menjadi sumber mata air yang sangat kuat kemajuan manusia, kemakmuran, dan kreativitas (Schuck, 2002).

Konsep warga negara liberal sebisa mungkin meminimalisir peran negara. Sehingga warga negara diberikan kebebasan sebesar mungkin untuk menggunakan kemerdekaannya untuk kepentingan sendiri. Hal ini kemudian yang menyebabkan warga negara terjebak dalam egoisme semata dan meniadakan solidaritas di antara individu dalam komunitas (Ahida, 2005).

Tabel 1. Keuntungan dan Kekurangan Gagasan Konsepsi Liberal

\begin{tabular}{|c|c|c|c|}
\hline No & Keuntungan & & Kekurangan \\
\hline 1 & Demokrasi lebih stabil & & Kesenjangan mudah terlihat \\
\hline 2 & Lebih Toleran & & $\begin{array}{l}\text { Fokus pada kekayaan dan } \\
\text { material }\end{array}$ \\
\hline 3 & Masyarakat kreatif dan mandiri & & Negara relatif lebih lemah \\
\hline 4 & $\begin{array}{l}\text { Memiliki kesempatan yang } \\
\text { mengembangkan diri }\end{array}$ & sama & $\begin{array}{l}\text { Kurang tertarik dalam bidang } \\
\text { politik }\end{array}$ \\
\hline
\end{tabular}

Secara lebih luas, Thun (2016: 76) menggambarkan konsep kewargaenagraan liberal.

Tabel 2. Dimensions of Citizenship

\begin{tabular}{lllll}
\hline & Rights & Membership & Participation & Identity \\
\hline Liberal & Individual & Internally & As a right & No explicit \\
& Legal & inclusive & No reference to & reference, but \\
& Protected & (territorially & market & notions of \\
by EU law & limited) & participation & $\begin{array}{l}\text { belonging based } \\
\text { on rights? }\end{array}$ \\
\hline
\end{tabular}

\section{Republikan}

Republika berasal dari kata Latin res puclica yang artinya masyarakat atau benda umum, urusan dan properti. Ada dua kata kunci dari Republika yakni Publisitas (publicity) dan pemerintahan sendiri (self government). Publisitas adalah kondisi di mana lebih terbuka dan bersifat umum yang diutamakan sedangkan pemerintahan sendiri berangkat dari asumsi klasik keterlibatan atau pentingnya partisipasi langsung warga negara (Dagger, 2002). Berbeda dengan liberalisme, republikan memandang individu secara kelompok dalam pergaulannya memiliki potensi yang positif dan baik terhadap kehidupan politik (Honohan, 2017). Sehingga ciri yang melekat dalam republikan dan tidak ditemukan dalam konsep kewarganegaraan lainnya adalah sifat eksklusifitasnya (Abowitz \& Harnish, 2006).

Dagger (2002) menambahkan bahwa publisitas dan pemerintahan sendiri merupakan ciri khas dari gagasan republik. Sekalipun sesungguhnya hal itu tidak istimewa. Sebab, baik republik maupun liberal sesungguhnya menekankan pentingnya pemerintahan sendiri namun dengan cara yang berbeda. Sullivan (1986), Sandel (1996), dan Pettit (1997) berpendapat liberalisme memberi terlalu 
banyak memperhatikan privasi dan hak individu dan terlalu sedikit untuk menumbuhkan kebajikan publik yang menuntun orang untuk melakukan tugasnya sebagai warga negara. Liberal dan republiken keduanya ingin mempromosikan pemerintahan sendiri (Dagger, 2002).

Oleh karena itu, kaum liberal membuat kesalahan dalam berpikir bahwa semua bentuk pengekangan menghalangi orang untuk kebebasan. Padahal pengekangan yang diberlakukan oleh sistem hukum itu mencegah beberapa orang memerintah atau mendominasi orang lain. Maka konsep republikan menekankan pentingnya pembatasan pemahaman hak-hak warga negara (Kivisto \& Faist, 2007).

Republikan dalam republikan kemudian diikuti dengan penekanan pentingnya konsep keteraturan hukum (rule of law) dan kebajikan publik (civic of virtue). Hal ini didasari bahwa urusan publik setidaknya bukan tujuan kenyamanan semata melainkan mencegah terjadinya penyimpangan. Selain itu, publik yang bersemangat dalam kebajikan publik harus diikat dalam keteraturan hukum (rule of law). Dalam urusan publik, politik biasanya membutuhkan debat yang pada gilirannya membutuhkan prosedur teratur dan jelas, yaitu: peraturan tentang siapa yang boleh berbicara, kapan mereka berbicara, dan bagaimana keputusan harus dicapai. Keputusan kemudian harus diambil bentuk aturan atau dekrit yang diundangkan yang memandu perilaku anggota publik. Dari desakan publisitas, aturan hukum dengan juga semakin dibutuhkan. Oleh karena itu, dalam republikan bentuk kebebasan individu hanya aman dalam keadaan bebas adalah di bawah hukum (Dagger, 2002).

Dalam pandangan republikan, warga negara memiliki status etis sebagai salah satu dimensi hukum (Dagger, 2002). Bukan berarti merendahkan posisi warga negara sebagai subjek hukum. Sebab warga suatu komunitas diatur oleh aturan hukum harus seseorang yang memegang hak dan kewajiban hukum keanggotaan. Oleh karena itu dibutuhkan pelengkap yakni dimensi etis. Maka pertimbangan etis ini, warga negara bisa dikategorikan warga negara baik dan buruk. Hal ini yang tidak bisa dinilai jika warga negara hanya didasarkan pada status legal semata.

Penekanan dimensi etis merupakan dimensi standar dalam republik. Hal ini berbeda dengan liberal yang menekankan kewarganegaraan berdasarkan status legal semata. Penekanan tentang partisipasi secara publik dalam pembuatan keputusan kolektif merupakan kewajiban politik fundamental dalam republikan (Kartal, 2001).

Berbeda dengan liberalisme yang mencoba meminimalisir peran negara, dalam republikan justru sebaliknya. Negara dituntut untuk lebih aktif menegakkan hukum dan kebajikan-kebajikan publik (Maynor, 2003). Berikut adalah tabel konsep Republikan yang membedakannya dengan liberalisme.

Tabel 3. Tradisi Kewarganegaraan Liberal dan Republikan

\begin{tabular}{llllll}
\hline Konsepsi & $\begin{array}{c}\text { Gagasan } \\
\text { tentang } \\
\text { Kebebasan }\end{array}$ & $\begin{array}{c}\text { Unit } \\
\text { Referensi }\end{array}$ & $\begin{array}{c}\text { Faktor } \\
\text { Konstruktif }\end{array}$ & $\begin{array}{c}\text { Tipe } \\
\text { Warga } \\
\text { Negara }\end{array}$ & Inti Politik \\
\hline Liberal & Negatif & Individu & Hak & Pasif & $\begin{array}{l}\text { Persamaan } \\
\text { di depan }\end{array}$ \\
& & & & & $\begin{array}{l}\text { Hukum } \\
\text { Hepublikan }\end{array}$ \\
\hline Positif & Komunitas & Kewajiban & Aktif & Partisipasi \\
\hline
\end{tabular}

Sumber: Effendi (2018). 


\section{Komunitarian}

Dalam pandangan komunitarian, konsepsi liberal dan republik memberikan pemahaman yang tipis dan dangkal terhadap komunitas khususnya budaya. Dengan demikian, berbeda dengan liberal yang menempatkan kewarganegaraaan pada individu, komunitarian menganggap kewarganegaraan berada pada defenisi budaya. kewarganegaraan sebagai anggota komunitas politik bertumpu pada individu ataukomunitas budaya atau moral masih menjadi perdebatan sejauh ini (Delanty, 2002).

Menurut Delanty (2002) komunitas adalah organisasi dan ikatan sosial masyrakat secara tradisional sedangkan masyarakat adalah fragmentasi dunia modern yang intelelktual, rasional, dan terstruktur secara individual. Tonnies (Delanty, 2002) menambahkan komunitarian berdasarkan ikatan secara langsung sedangkan masyarakat berdasarkan ikatan asosiasi. Konsep komunitarian berasumsi dari pandangan Antropologi klasik yang mengabadikan mitos klasik bahwa masyarakat menyatu secara holistik dalam tatanan simbolik dan nilai-nilai primordial (Delanty, 2002). Komunitas juga secara wilayah hidup dalam teritori yang sama dan memiliki nilai-nilai yang sama pula.

Secara umum, konsep kewarganegaraan dalam komunitarian ialah sebagaimana digambarkan oleh Thun (2016: 76) berikut ini.

Tabel 4. The Communitarian Model and the Four Dimensions of Citizenship

\begin{tabular}{llll}
\hline Right & Membership & Participation & Identity \\
\hline Cultural/Collective & Cultural & Duty & Cultural/ethical/Ethnic \\
Collective goods & Connected to a & The politically & All individuals are \\
and benefits & cultural & active citizen & born with an identity \\
& defined & Citizenship as & in a cultural defined \\
& community & a political & territory, which make \\
& Exclusive & practice & up the foundations for \\
& & & citizenship \\
& & & Rejection of \\
& & individualism \\
\hline
\end{tabular}

\section{METODE PENELITIAN}

Metode yang digunakan yang digunakan dalam penelitian ialah dengan pendekatan kualitatif dengan menggunakan metode studi kepustakaan (library research). Sumber-sumber yang digunakan adalah berupa buku, jurnal penelitian, dokumendokumen kebijakan, dan berbagai referensi yang dianggap sesuai dengan topic yang dikaji. Data selanjutnya diolah dan dianaisis secara induktif.

\section{HASIL DAN PEMBAHASAN}

\section{Pendekatan Kewarganegaraan Indonesia}

Untuk melihat pendekatan yang digunakan dalam konteks Indonesia bisa dilakukan dengan melihat tujuan dan bentuk negara, tujuan-tujuan pendidikan kewarganegaran, dan nilai-nilai yang diajarkan dalam pendidikan kewarganegaraan atau yang disebut dengan Pendidikan Pancasila dan Kewarganegaraan (PPKn) sesuai dengan kurikulum yang digunakan saat ini yaitu Kurikulum 2013. 
Dalam konstitusi Indonesia, UUD NRI Tahun 1945 secara jelas disebutkan bahwa Negara Indonesia ialah Negara Kesatuan berbentuk Republik (Pasal 1 ayat (1). Sekalipun mengakui sebagai sebuah negara republik, namun dalam konstitusi juga mengakui pentingnya pengakuan warga negara secara individual. Hal ini setidaknya ditandai dengan munculnya BAB khusus tentang Hak Asasi Manusia (HAM) dalam BAB X UUD NRI hasil amandemen.

Di sisi lain, Indonesia juga nyatanya mengakui dan melindungi warga negara secara budaya. Dalam Pasal 32 disebutkan dengan jelas bahwa negara memajukan kebudayaan nasional di tengah peradaban dunia dengan menjamin kebebasan masyarakat dalam memelihara dan mengembangkan nilai-nilai budayanya (Ayat 1). Dari hal ini bisa dipahami bahwa negara juga mengakui bahwa warga negara tidak bisa dipisahkan dari budaya, komunitas, dan kearifan lokal yang sudah ada sejak lama sebelum Indonesia merdeka.

Tujuan pendidikan nasional dalam Pasal 3 disebutkan ialah berkembangnya potensi peserta didik agar menjadi manusia yang beriman dan bertakwa kepada Tuhan Yang Maha Esa, berakhlak mulia, sehat, berilmu, cakap, kreatif, mandiri, dan menjadi warga negara yang demokratis serta bertanggung jawab. Penekanan menjadi warga negara yang demokratis dan bertanggung jawab merupakan konsep kewajiban yang secara implisit harus dimiliki oleh setiap warga negara. Setiap orang harus berakhlak mulia, sehat, berilmu, cakap, kreatif, mandiri namun harus dibarengi dengan sikap yang demokratis dan bertanggung jawab.

Dalam pendidikan di Indonesia, pendidikan kewarganegaraan dilakukan secara subjek yang terpisah yang dikenal dengan Pendidikan Kewarganegaraan sesuai dengan Kurikulum 2013 yang saat ini masih digunakan. Dalam penjelasan Peraturan Pemerintah No. 32 Tahun 2013 tentang Standar Pendidikan Nasional dijelaskan bahwa pendidikan kewarganegaraan bertujuan untuk "membentuk Peserta Didik menjadi manusia yang memiliki rasa kebangsaan dan cinta tanah air dalam konteks nilai dan moral Pancasila, kesadaran berkonstitusi Undang-Undang Dasar Negara Republik Indonesia 1945, nilai dan semangat Bhinneka Tunggal Ika, serta komitmen Negara Kesatuan Republik Indonesia."

Tujuan umum Pendidikan Kewarganegaraan ialah mengembangkan potensi peserta didik dalam seluruh dimensi kewarganegaraan, yakni: (1) sikap kewarganegaraan termasuk keteguhan, komitmen dan tanggung jawab kewarganegaraan (civic confidence, civiccommittment, and civic responsibility); (2) pengetahuan kewarganegaraan (civic knowledge); (3) keterampilan kewarganegaraan termasuk kecakapan dan partisipasi kewarganegaraan (civic competence and civic responsibility).

Hal senada dikatakan oleh Fearnley-Sander \& Yulaelawati (2008: 116). Dalam konteks kurikulum Indonesia yang mencoba membentuk karakter/watak warga negara Indonesia hendaknya memuat: (a) a commitment to Pancasila as the source of national identity; (b) a commitment to civic competency, and; (c) a rightsoriented view of citizenship.

Dalam Peraturan Kementerian Pendidikan dan Kebudayaan 20 Tahun 2018 tentang Penguatan Pendidikan Karakter pada Satuan Pendidikan Formal dijabarkan nilai atau karakter yang hendak diwujudkan dalam setiap pembelajaran formal Pasal 2 ayat(1) yang dianggap merupakan jabaran dari Pancasila yaitu religius, jujur, toleran, disiplin, bekerja keras, kreatif, mandiri, demokratis, rasa ingin tahu, 
semangat kebangsaan, cinta tanah air, menghargai prestasi, komunikatif, cinta damai, gemar membaca, peduli lingkungan, peduli sosial, dan bertanggung jawab.

Karakter-karakter diatas diharapkan senantiasa muncul atau dipraktik siswa dalam setiap pembelajaran. Ke-18 karakter tersebut merupakan perwujudan dari 5 (lima) nilai utama yang saling berkaitan yaitu religiusitas, nasionalisme, kemandirian, gotong royong, dan integritas yang terintegrasi dalam kurikulum (Ayat 2). Hal ini dikarenakan sebagaimana ditegaskan Fearnley-Sander \& Yulaelawati (2008) dalam kurikulum di Indonesia harus ada "a commitment to Pancasila as the source of national identity".

Warga negara dalam konteks Pancasila berbeda dengan kewarganegaraan baik dalam liberal, republikan maupun komunitarian. Sekalipun berbeda, Kewarganegaraan dalam konteks Pancasila tidak menolak nilai-nilai yang baik diantara ketiganya bahkan cenderung untuk mengintegrasikannya. Hal senada ditegaskan oleh Latif (2015) bahwa Pancasila sebagai ideologi negara dapat dikatakan sebagai ideologi integralistik yang mengatasi partikularitas paham perseorangan dan golongan. Dalam pandangan ideologis pendidikan di Indonesia khususnya pendidikan kewarganegaraan, wilayah pribadi atau keluarga dan komunitas etnis agama dan golongan masyarakat, setiap perseorangan dan golongan masih bisa mengembangkan partikularitas ideologinya masing-masing.

Hal ini menurut Latif (2015) disebabkan karena antara wilayah privat komunitas dan publik itu bisa dibedakan secara kategoris, dalam realitas hidup tidak selalu bisa dipisahkan. Menurut ideologi Pancasila ketiga wilayah itu tidak sepenuhnya terpisah. Meski demikian berbeda pula dengan paham kolektivisme totalitarian ala libertarian socialism yang bisa semena-mena mengintervensi wilayah privat.

Dengan demikian, Pendekatan pendidikan kewargaengaraan di Indonesia atau bisa disebut dengan pendekatan Pancasilais memandang sumber sumber mora privat dan komunitas atau agama kearifan lokal dan lain-lain bersifat mutalistik bukan negasi segregatif satu sama lain. Dengan demikian, Pancasila tidak bermaksud mengintervensi pengembangan moral privat dan komunitas namun bisa mencegah secara hikmat bijaksana pengembangan moral privat dan komunitas yang dapat membahayakan kehidupan publik (Latif, 2015).

\section{KESIMPULAN}

Pendekatan Pendidikan Kewarganegaraan di Indonesia tidak bisa ditentukan secara pasti jika mesti mengikuti konsep kontemporer Barat antara Liberal, Republikan, dan Komunitarian. Pancasila memiliki pandangan, ide, dan gagasan ideal tersendiri tentang konsep kewarganegaraan ideal. Pendekatan tersebut bisa disebut dengan pendekatan Pancasila. Pendekatan Pancasila bukan antitesis dari ketiga pendekatan kewarganegaraan di atas. Justru Pancasila baik secara langsung atau tidak, sengaja atau tidak berusaha mempertemukan anasir-anasir ketiganya dengan begitu cermat. Anasir-anasir ketiga diformulasikan dan diidealisasikan sebagai konsep warga negara ideal di Indonesia. Pengarusutamaan moralitas dan kepentingan publik juga sangat kentara dalam nilai dan muatan yang diajarkan dalam pendidikan kewarganegaraan. Lima nilai religiusitas, nasionalisme, kemandirian, gotong royong, dan integritas yang terintegrasi dalam kurikulum pendidikan mengafirmasikan bahwa warga negara diharapkan bersifat republikan. Nilai-nilai yang bersifat invidu atau privat menjadi bagian yang tidak terpisahkan dalam 
Pendekatan Kewarganegaraan Indonesia

konsepsi Pancasila. Muatan Pasal-Pasal Hak Asasi Manusia yang dijabarkan dari Pasal 28 A hingga 28J UUDNRI Tahun 1945 mengafirmasikan bahwa wilayah privat menjadi nilai inti Pancasila. Berbeda dengan pendekatan kewarganegaraan lain, Pancasila mencoba untuk mensistesiskan ketiga pendekatan tersebut dalam rumusan yang dikenal dengan Pancasila.

\section{REFERENSI}

Abowitz, K. K., \& Harnish, J. (2006). Contemporary discourses of citizenship. Review of educational research, 76(4), 653-690.

Ahida, R. (2005). Liberalisme dan Komunitarianisme: Konsep tentang Individu dan Komunitas. Jurnal Demokrasi, 4(2), 95-106.

Dagger, R. (2002). Republican Citizenship. Handbook of citizenship studies, 145157.

Delanty, G. (2002). Communitarianism and Citizenship. Handbook of citizenship studies, 161-174.

Effendi, W. R. (2018). Konsepsi Kewarganegaraan dalam Perspektif Tradisi Liberal dan Republikan. Jurnal Trias Politika, 2(1), 55-62.

Faulks, K. (2002). Citizenship. In G. Blakeley \& V. Bryson (eds). Contemporary Political Concepts: A Critical Introduction, pp. 73-89. London: Pluto Press.

Fearnley-Sander, M., \& Yulaelawati, E. (2008). Citizenship discourse in the context of decentralisation: The case of Indonesia. In Citizenship curriculum in Asia and the Pacific (pp. 111-126). Springer, Dordrecht.

Forde, S. (2009). The Charitable John Locke. The Review of Politics, 428-458.

Gardner, E. C. (1993). John Locke: Justice and the social compact. Journal of Law and Religion, 9(2), 347-371.

Honohan, I. (2017). Liberal and republican conceptions of citizenship. The oxford handbook of citizenship, 83. Oxford: Oxford University Press.

Isin, E. F., \& Turner, B. S. (Eds.). (2002). Handbook of citizenship studies. London: Sage.

Kartal, F. (2002). Liberal and republican conceptualizations of citizenship: A theoretical inquiry. Turkish Public Administration Annual, 27(2001-2002), 101-130.

Kivisto, P., \& Faist, T. (2009). Citizenship: Discourse, theory, and transnational prospects. Malden: John Wiley \& Sons.

Kymlicka, W. (1995). Multicultural citizenship: A liberal theory of minority rights. Oxford: Clarendon Press.

Latif, Y. (2015). Revolusi Pancasila. Mizan: Jakarta.

Maynor, J. W. (2003). Republicanism in the modern world. Cambridge: Polity Press.

Nain, A. S. M., \& Yusoff, R. (2003). Konsep, Teori, Dimensi dan Isu Pembangunan. Malaysia: Penerbit UTM.

Osler, A., \& Starkey, H. (2006). Education for democratic citizenship: A review of research, policy and practice 1995-2005. Research papers in education, 21(4), 433-466.

Pettit, P. (1997). Republican political theory. Political theory: Tradition, diversity and ideology, 112-132. 
Sandel, M. J. (1996). America's search for a new public philosophy. AtlanticBoston, 277, 57-88.

Schuck, P. H. (2002). Liberal citizenship. Handbook of citizenship studies, 131144.

Sullivan, W. M. (1986). Reconstructing public philosophy. Los Angeles: University of California Press.

Thun, V. (2016). Liberal, Communitarian or Cosmopolitan? The European Commission's Conceptualization of EU Citizenship. Oslo, Norway: ARENA report.

Tuckness, A. S. (1999). The coherence of a mind: John Locke and the law of nature. Journal of the History of Philosophy, 37(1), 73-90.

Vincent, A. (2010). The politics of human rights. Oxford: Oxford University Press. 